\title{
TOWARD AN OBJECTIVE ISLAMIC STUDIES
}

\author{
Karimatul Khasanah \\ Doctorate Student, UIN Sunan Kalijaga Yogyakarta \\ karimatulkh.rima@gmail.com
}

\begin{abstract}
One of the issues that haunts contemporary Muslim scholarship is the objectivity of the study of Islamic Studies which they strive for. Among them are groups called insiders and outsiders. Insiders as Islamic reviewers come from Muslims, while outsiders are reviewers of non-Muslims who are often called orientalists. If insiders are considered to be less objective because of their ideological interests as the adherents of Islam, the outsider's unobjectivity is due to their propaganda-oriented study. The problem eventually leads to the solutioncoming upfrom some prominent scholars' ideas in Islamic Studies, among them are Kim Knot, Abdur Rouf, and Fazlur Rahman. Kim Knot produced a Spatial theory, Abdur Rauf initiated an Empatic Understanding, while Fazlur Rahman formulated objectivity theories. Those three try to make efforts to bridge between insider and outsider so that each can do an objective study, which is not ideologically-subjective biased. This is called intersubjectivity in religious studies.
\end{abstract}

Keyword: Insider, Outsider, Islamic Studies, Objectivity.

\section{A. Introduction}

slamic Studies ${ }^{1}$ is one of the studies that has been receiving widespread attention among scholars, both Western and Eastern. If explored in depth, it can be seen that the interest of Islamic studies began to bloom since the second half of the $19^{\text {th }}$ century. Many Islamic studies departments now are masde as one of the favorite branches of science. This means the study has a place in the world of science. To support this assumption, in the West are many universities that open faculties or departments specialized in Islamic studies as well as the books and journals to publish.

The main problem dealing with Muslims when studying Islam lies not in the lack of mastery of material, but rather on ways of presenting the material being mastered. It is more about the methodological problem. Harun Nasution once said that the weakness among Muslims in comprehensively studying Islam is that they are not capable of mastering the methodology. ${ }^{2}$

Nowadays, the Islamists who stand in the tradition of orientalism have been increasingly under attack due to their academic provincialism and actions on distorting image of the Islamic society. The position of people who want to ask "how" to study Islam as a religion is confused by the tendency to compartmentalization in higher education.

\footnotetext{
${ }^{1}$ Harun Nasution, Islam Ditinjau Dari Beberapa Aspek, (Jakarta: Bulan Bintang, 1985), 33.

${ }^{2}$ Richard C. Martin, Approaches to Islam in Religious Studies, terj. Zakiyuddin Baidhawy, Pendekatan Kajian Islam dalam Studi Agama (Muhammadiyah University, 2001), 52.
} 
The problems of outsider and insider also become academic language of religion. Who is most competent to talk to others about Islam, Muslim scholars (insider) or Western scholars and orientalists (outsiders)? In this paper, the question will be the subject of the study on which the author will base by presenting a critical reading of the three concerned figures in it, namely Kim Knot, Abdur Raouf, and Fazlur Rahman.

\section{B. Discussion}

\section{Insider \& Outsider}

Before deeply entering to discussion, it is in need to explain the term insider and outsider. Insider covers scholars of religion from their own religion (insiders). While the outsider are a scholars of religion who are not the adherents ofthe religion. The problem is whether the insider or outsider in the assessment is really objective and can be accounted for, because the background and the histosrical trap that is attached to both. Many keep a negative view on the opinion of outsiders. There is suspicion based on reason that the number of Western interests against Islam is one form of political propaganda trap to continue to control the territory of an Islamic state and to strengthen the roots of the occupation of the state.

The above description gives an indication that many analytics from the outsider can not be accepted by the insider, ${ }^{3}$ and so much insider analysis that is considered by the eyes of the outsider because of the subjectivity that ensnare the insider. If this is allowed to drag on it will only lead to miss-understanding that can lead to conflict. Dissatisfaction with the reality, experts and researchers seek to identify and construct theories to solve problems surrounding religious studies.

\section{Initiated Ideas}

The following subtitle is where the author elaborates the thoughts of Kim Knot, AbdurRouf and FazlurRahman about the objectivity of research / religious studies that have a close relationship with insider and outsider problems in Islamic Studies.

\section{Kim Knot (Spatial Theory)}

Kim Knott has reviewed the works of previous research before offering his new ideas in religious studies, among the works that he read are like the works of Mircea Eliade, Rudolf Otto, Wilfred C. Smith, Cornelius Teile, Van der Leeuw, Kenneth Pike, Ninian Smart and others. Departed from these works, Kim Knott tries to offer his thoughts on religious studies and to solve problems in religious research that has been a problem among academics and adherents.

Methods in previous religious studies such as the emergence of orientalism and occidentalism, insider and outsider still cannot reveal the objectivity of the research. He

\footnotetext{
${ }^{3}$ W.C. Smith in Comparative Religion in Mircea Eliade and Joseph Kitagawa (ed). in Muhyar Fanani, Metode Studi Islam, (Yogyakarta: Pustaka Pelajar, 2010), XXII.
} 
offers that there are 4 (four) categories in this issue, namely pure participants, ${ }^{4}$ pure researchers, ${ }^{5}$ researchers as participants, ${ }^{6}$ participants as researchers. ${ }^{7}$

The categorization model by Kim Knot is completed with one theory. The theoretical framework of the theory begins with the thought of a mixture of doctrinal-theological aspects in sociological cultural struggle, which adds to the increasing complexity of the problem of religion in the area of historicity of humanity. By doing so, it can be disclosed which is doctrine (normative), and whichever is the interpretation of a person or group that is against a doctrine that is often contained or mixed with the interests of cultural-sociological interests, which in many cases is very difficult to distinguish. For researchers to dissolve or at least clarify the mixing of doctrinal-theological and cultural dimensions of sociology, it is necessary to use a spatial approach.

Based on the views of experts, there is a relationship between religion, culture and society. Kim Knot in 2001 began to develop a scientific method with an approach called "Spatial" to analyze the location of religion in society. Kim Knot sees the difference when religion resides in an organization, movement, society, places of worship. Kim Knot's big question is why religions are different whereas they come from the same source? And how do religions take place in that dimension? ${ }^{8}$

His spatial approach starts out from space theories of Martin Heiddeger, Maurice Merleau-Ponty, Edward Cassey and Cristopher Tilley. From these theories, Knot developed and applied around the location of religion. These elements are: 1. Body as the source of space, 2. Space dimension, 3. Nature of space, 4. Aspects of space and 5. Space dynamics. ${ }^{9}$

Explanation of the body as a source of space is that a person can make interpretations related to the environment, the nature and patterns of public relations and the value of sanctity in society. ${ }^{10}$ The dimension of space is in which individuals and social as well as cultural differences blend into one unity. Differences in places will affect the culture and there is a new cultural and religious reproduction. ${ }^{11}$ The nature of space is not a picture of empty space. The space in question here is multi-dimensional. Economic networks between countries, cultures and languages mutually form a network. ${ }^{12}$ In the aspect of space, there are three interrelated things through which, space is understood, felt and occupied by people. ${ }^{13}$ The dynamics of space is closely related to power, history and time in a religious sense and will always co-relate and influenced by each of the three. ${ }^{14}$

\footnotetext{
${ }^{4}$ Kim knott, Insider/Outsider Perspectives dalam "the Routledge Companion to the Study of Religion”, Edited by John R. Hinnels (London: Routledge Taylor and Fancis Group, 2005), 245.

5 Ibid., 249.

${ }^{6}$ Ibid., 251-252.

7 Ibid., 247-252.

${ }^{8}$ Kim Knott, Spatial Theory and Method For the Study of Religion, (The Finish Society for the Study of Relegion, Temenos, Volume 41 No. 2, 2005) http://eprints. whiterose.ac.uk/2, accessed 1 February 2016.

${ }^{9}$ Ibid., 4.

${ }^{10}$ Ibid., 5.

${ }^{11}$ Ibid., 8.

12 Ibid., 10.

13 Ibid., 12.

${ }^{14}$ Ibid., 16.
} 
Spatial method is a method used in mapping religion, to know the dimensions that exist in religion. In the context of Islamic studies, spatial method is very useful to know the parts of religious and cultural elements. Religion understood today when dissected by spatial method will encounter the original element (that really comes from the holy book) and elements that come from religion. At this time, the original elements and culture are still mixed.

\section{Abdur Rauf (Emphatic-Understanding)}

In this section, the author refers to Muhammad Abdul Rauf's work, Outsider's interpretations of Islam: A Muslim's Point Of View. Insider and outsider studies are closely related to Western experience and Muslim scholars in interpreting and understanding Islam. Insider is an Muslim scholar of his own. While the outsider is a term for non-Muslim scholars who study Islam and interpret it in the form of analysis with a particular methodology.

The issue is whether the scholars of Islam from outsider are completely objective, accountable, and have scientific validity seen from optical insider? Abdur Rauf rejected the validity of outsiders as they studied Islam over the impulse of colonial interests in order to perpetuate political and economic domination over their conquered territories. Therefore, the study of Islam within the framework of thispoint of viewimplies "oriental studies" which have been actually done by European intellectuals for students at European universities. ${ }^{15}$

Therefore, Islamic studies by outsider in optical insider is full of biases, interests, and west-centered. Reading the work of outsiders about Islam must be done with very critical and careful. Especially if the study is about sacred texts it is required to have faith and this is not owned by any outsider.Rauf found numerous prejudices and dangers in Western Islamic studies. For example, the analysis of Islamic studies is based on cultural, religious, and intellectual prejudices based on cultural supremacy. ${ }^{16}$

Abdur Rauf vividly pointed out his anxiety over the works of Western scholars of Islam. He claimed that the works oftendiscredit Islam without paying attention to the voices of Muslim scholars in particular and all Muslims in general. In other words, scholars and Muslims seem to be present and may also be "got rid of". Islam is seen only as a stone, wood or other inanimate object that has no desire, desire, dream, and opinion to define itself.

At the beginning of his essay, Abdur Rauf discussed how Western attempts to colonize Islam through education. He gave examples of cases of modernizationsecularization that the West would undertake to Al-Azhar University in 1961.

According to him if such reforms occur, then the traditional Islamic scholarship that "authentic" little by little will shrink its influence. Coupled with the wave of information technology that tore down the barriers of culture and nation, it is no wonder that Muslims will "face and spiritually" West and leave their own face and soul, that is Islam. Fortunately, when the Muslims and the Egyptian President and the al-Azhar sheikhs refused so that

\footnotetext{
${ }^{15}$ Muhammad Abdul Rauf, Outsider's Interpretations of Islam: A Muslim's Point of View in Richard C. Martin, "Approaches to Islam in Religious Studies", USA: The University of Arizona Press. 182.

${ }^{16}$ Ibid., 193
} 
reforms were not made. Nevertheless, the West managed to reform the curriculum of other Islamic schools, namely by incorporating a secular curriculum in it. ${ }^{17}$

With this, then the above-mentioned fears finally happen. Traditional "authentic" traditional Islamic education has diminished its role, and post-West has established Westernstyle secular schools in Islamic countries (not Islamic States but Muslim-majority countries). Islamic educational institutions have narrowed their role, ie only as religious educational institutions. At this time (medieval) in the body of Islam occurs dichotomy between Islamic scholarship and non-Islam which never before terbesit in the mind of Islam, because according to Islam all knowledge is Islam or Divine.

Given the dichotomy of scholarship, Islamic scholarship for the East (Islam) and nonIslamic scholarship for the West (America and parts of Europe), it then brings out different methods and approaches between Western scholars and Muslim scholars in studying Islam. Westerners tend to use scientific methods and historical approaches and Muslim scholars tend to be more theological and ideological. Western Islamic studies is driven by the need for colonial power to learn and understand the communities they have been controlling, while Muslims' Islamic studiesis driven by self-defense. In addition, according to Abdur Rauf Western scholars in the study of Islam is strongly influenced by negative "preassumptions" which state that Islam is a violent, anti-modernizing, misguided religion, and brought by false prophets and sexuality. Therefore, the end result of Western studies is often objective and offensive to Muslims.

Islamic studies conducted in the West save a myriad of problems that need to address and deal with. One of them is the problem of Western researchers or orientalists as outsiders in understanding Islam. This case is not a trivial issue, given the fact that some of the essay of some Orientalists are very problematic according to the Muslims' views. Muhammad Abdur Rauf posed this issue critically.

Although he does not deny some of the fair-minded orientalists who have contributed to a good study of Islam, such as Henri Corbin's defense of Islamic Philosophy in Persia, he can not compromise with outside researchers who cross the limits of Muslim faith.

To him, "But it would be dangerous if, on behalf of scholarship, the origin of Islam is described as emerging from economic or cultural phenomena. Whatever could be said about Islam in respect of the place and time in which it arises, (but) its uniqueness and its claim to truth in the presence of its adherents is inexplicable. "

AbdurRauf'sanxietiessignpost the need for a new approach which is more adequate in understanding Islam. As history has shown how arbitrarily Islam is perceived by some orientalists because they do not put Islam as religion as what it is and what should be. This can be traced from the various stereotypes waged to Islam under the pretext of scholarship.

On the one hand, outsidersare required to gain a full and valid understanding of Islam they are examining, in accordance with the meaning and appreciation of insiders. On the other hand, the outsiders must also convey and inform their observations to audiences (to Western societies who are yet familiar with Islam) scientifically by their own language.

\footnotetext{
${ }^{17}$ Richard C. Martin, Approaches to Islam in Religious Studies, trans. Zakiyuddin Baidhawy, Pendekatan Kajian Islam dalam Studi Agama (Yogyakarta: Muhammadiyah University, 2001), 238.
} 
From here, it seems that there is the inevitability of cultural bias in the communication process. The people who get the information from the research of outsiders would understand through their cultural presumptions.

Nevertheless, our problem here is not that far. It is how scholarscould get adequate information about Islam. An answer from insiderwould not certainly be satisfactory to this crucial question for outsiders, since sometimes outsiders actually understand us more than ourselves.Or in other words, sometimes an orientalist has better understanding in some aspects of Islam than Muslims themselves. The reality confirms that the contribution of orientalists in Islamic studies is very enormous, for example in presenting the influence of Islamic civilization on European civilization.

Based on the above matters, according to AbdurRauf, Western scholars of Islam must release the "pre-assumption" and takeinto account the opinion and voice of Muslims over him. In fact, for him, to study Islam, particularly related to faith and doctrine, Western scholars should use the methods used by the Muslims or left just like what is said by Muslims. Then, it is clear that his criticism toward the method of Islamic studies in the West should move from explanation to emphatic or understanding.

In addition, to make a comprehensive understanding of the West over Islam, AbdurRauf also advised scholars and Muslims to be able to voice up themselves to the West and to strive to take positive things out of modernization and without abandoning the rich Islamic tradition. This, according to the author's opinion, is aimedbyAbdurRaufto make Muslims able to dialogue with Western civilization, not the other way around i.e., Muslim scholars and Muslims arewesternized and imagined by the West. In short, AbdurRauf does not reject the whole reform, but must be adapted to the context and scope of its territory.

However, Abdul Rauf also took a more cautious view of the outsider issue. He did not simply reject the orientalists works, sometimes even accept the views of Islam advanced by some orientalists. ${ }^{18} \mathrm{He}$ did not simply generalize Western orientalists works. In his point of view, not all orientalists works should be rejected and considered useless, because among them aresome honest orientalist (fair-minded orientalist). Rauf did not deny the existence of biases and distortions that arise from the orientalists. Yet, such thing only occurs if the orientalist is dishonest.

\section{Fazlur Rahman (Approach-Method)}

Fazlur Rahman's thought related to Islamic studies which relates to the objective discourse of study/research by insiders and outsiders, is actually constructed from several academic anxieties that have long become his concern. Among his academic anxieties are:

Firstly, the condition of Muslims experiencing a methodological crisis which is one of the causes of the decline of Islamic thought.In his remark, methodology is the center point of intellectual crisis resolution. Secondly, in the era of the early companions of the first period, Muslims used two main sources of law, namely the Qur'an and Hadith,in dynamic and historical ways. Unfortunately, at the end of the period I and the beginning of the second

\footnotetext{
${ }^{18}$ Muhammad Abdul Rauf, "Interpretasi Orang Luar tentang Islam: Sudut Pandang Muslim”, Ricard C. Martin (ed), Pendekatan Kajian, 237-248.
} 
period, the religious thought of Muslims became normative, rigid and formal. Accordingly, the results of thought turned into ahistorical and dogmatic. Thirdly, there is a misconception of Western scholars in understanding the Sunnah of the Prophet that caused them to reject the Sunnah of the Prophet. Fourthly, there is the incompatibility of Sunnah-Ijtihàd-Ijmāand the evaluation and development of the Sunnah of the Prophet into Hadith. ${ }^{19}$

Seeing this phenomenon, Rahman asserted that Muslims need re-deconstruction/ deconstruction of scientific methodology in Islamic studies. Since this is the only solution to solve the intellectual crisis of Muslims and to rise from prolonged stagnation.

\section{Approach}

Before breaking down the method, it's good if we first alludes to the approach (approach) that Rahman used as the object of forma in studying Islamic thought. Of the many approaches used, in general, throughout the author's findings, the approaches used by Rahman in exploring contemporary Islamic discourse materials arehermeneutics, sociology, history and phenomenology.

First, the Hermeneutics approach, a new device adopted from western philosophical discourse used to interpret ancient texts such as scripture, history, law and philosophy. The word hermeneutics itself is often associated with Hermes -aninterpreter of God's message in ancient Greek beliefs. Then this tradition is developed into the interpretation of scriptures such as Bible. Although hermeneutics was originally used by Christians in interpreting the Bible, it was because Rahman saw some positive aspects that were contributive to the interpretive tradition, he adopted it into the Qur'an. From this approach,Rahman produced a systematic interpretation theory- doublemovement theory. In this approach, he is much influenced by Gadamer, a contemporary hermeneutic expert.

Second, the Sociological Approach, an approach that focuses its study on the social settings of society, including humanities. This is based on the main principles of Islamic Shari'ah i.e., the maqāsidshari'ahwhich considers heavily on the benefit of mankind with its hierarchy (dharuriyyat(primary), hajiyyat(secondary) and tahsiniyat (tertiary)). This approach necessitates the dialectics of the text with the context. The theory of contextual interpretation was born from this approach.

Third, the Historical Approach, an approach that looks at aspects of Islamic history. In this approach, Rahman tended, in detail, to make historical criticism linked to the development phase, the progress and decline of Muslims. It is purely intended to methodological reconstruction.

Fourth, the Phenomenological Approach, an approach that formulates a conception based on the existing phenomenon so that any conceptual formulation produced will always be relevant and applicable to the phenomenon, not just a mere formulation of conception.

\footnotetext{
${ }^{19}$ Hujair, AH. Sanaki, “ Pemikiran Fazlur Rahman Dalam Metodologi Sunnah dan Hadits “, Al-Mawridi XVI, $2006,256$.
} 


\section{Method}

The methods mentioned here are Rahman's "recipes" in blending Islamic thoughts, which principally leads to two main sources of mutual consensus, namely the Qur'an and Sunnah. The question posed is how the steps combine these two basic sources? In general, the methods used by Rahman in formulating the discourse of Islamic scholarship are Double Movement method, Logical Synthesis method, Inductive method and Integrative method.

\section{Conclusion}

Some of exposure and insight to the discourse of insider/ outsider theme, seem that the scholars of Islamic/ Muslim civilization still have to define their attitude to be clearer, objective, and consistent to the insider/ outsider or with orientalists. It is due to the fact that modern Islamic scholars nowadays develop an academic authority based on their academic experience with orientalists or with Non-Muslim Western scholars.

Kim Knot, Abdul Rauf and FazlurRahman have taken a more careful view of the outsider issue. They did not simply reject orientalists' works, sometimes even accepted the views of Islam put forward by some orientalists. They did not also just generalize Western orientalists' works. They did not deny that there are biases and distortions made upby some orientalist.

Regardless of the debate, as the end of this discussion, the author expresses his appreciation for the serious efforts of Western scholars who help "us" to learn more about Islam. Through exhausting efforts, many of them have made a useful contribution to our knowledge without violating the substance of Muslim scholarship, the Prophet, or the meaning of the Qur'an.

Such people look at Muslims as self-righteous societies, not as subjects of personal and group tendencies or just as objects of curiosity. However, it does not deny the existence of many non-Muslim Western scholars who deliberately discredit Muslims because of their personal or group tendencies, which cannot be separated from economic, political or cultural backgrounds. This phenomenon provides us reasonsto always be critical to the outsiders and their works, which we can still use to be researched and studied more deeply.One of which is their historical approach to the problems of Islam.

Finally, the more important thing is their awareness of the need for the genealogy of an idea or doctrine. All of these are apologetically possible to refute the orientalist's opinions, but the more genuine may be to find information we need in order to understand our own religion and culture as a tolerant and critical insider. 


\section{Bibiliography}

Abdullah, Amin dkk, Antologi Studi Islam: Teori dan Metodologi, Yogyakarta: Sunan Kalijaga Press, 2000.

Fanani, Muhyar, Metode Studi Islam, Yogyakarta: Pustaka Pelajar, 2010.

Kim, Knott, Insider/Outsider Perspectives; The Routledge Companion to the Study of Religion, Edited by John R. Hinnels, London: Routledge Taylor and Fancis Group, 2005.

, Spatial Theory and Method For the Study of Religion, The Finish Sosiety for the Study of Relegion, Temenos, Volume 41 No. 2, 2005.

Martin, Richard C., Approaches to Islam in Religious Studies, terj. Zakiyuddin Baidhawy, Pendekatan Kajian Islam dalam Studi Agama. Yogyakarta: Muhammadiyah University, 2001.

, Approaches to Islam in Religious Studies, trans. Zakiyuddin Baidhawy, Pendekatan Kajian Islam dalam Studi Agama, Yogyakarta: Muhammadiyah University, 2001.

Nasution, Harun, Islam Ditinjau Dari BeberapaAspek, Jakarta: Bulan Bintang, 1985.

Nugroho, Heru, Menumbuhkan Ide-Ide Kritis, Yogyakarta: Pustaka Pelajar, 2003.

Rahman, Fazlur, Hermeneutika Al-Qur'an FazlurRahman, Yogyakarta: Jalasutra, 2007. 
